\title{
真空チャックのアルミ合金製部品と鋼製主軸の 締結部における等価摩擦係数*
}

\author{
横山和 宏** \\ Equivalent Friction Coefficient on the Connecting Portion \\ between Aluminum Alloy Part and Steel Spindle of Vacuum Chuck \\ Kazuhiro YOKOYAMA

\begin{abstract}
This paper describes the equivalent friction coefficient on the connecting portion between chuck-part made of aluminum-alloy and spindle made of steel, which is obtained in the experiment. The tangential force is loaded by a PZT-element in the direction perpendicular to the bolt thrust. The tangential force and the bolt thrust are measured with load-sensor of Kistler and A/D converter, and the equivalent friction coefficient is calculated as the ratio of those forces. It is clarified that the equivalent friction coefficient of $0.15-0.25$ is reasonable near the start of sliding displacement as the boundary condition of FEM analysis and that the coefficient gradually increases with the increase in sliding displacement between chuck-part and spindle under small displacement.
\end{abstract}

Key words: equivalent friction coefficient, vacuum chuck, aluminum-alloy, steel, PZT-element, load-sensor

\section{1. 緒言}

超精密加工に用いられる真空チャックには，鋼製主軸の端 面にアルミ合金製チャック部品をボルト締結したものがあ る.このチャック部品の表面には真空引き用の溝があり， 工作物を吸着固定して加工を行う。平面度が良好なチャッ ク部品表面を得るためには, 機上で上記表面を超精密切削 することが必要であるので，アルミ合金製の部品を組み合 わせる構造になっている。

この場合，主軸回転による発熱や室温変化にもとづいて， 上記のチャック部品と主軸はほとんど同一の温度変化を示 す，両者が温度上昇すると，アルミニウム合金製のチャッ ク部と鋼製主軸の熱膨張量の差に基づく拘束力が鋼製主軸 との接触面において，チャック部品の中心方向に作用しモ 一メントを加えることになるので, 工作物を吸着固定する チャック表面の平面度が低下するというメカニズムを実験 により明らかにした ${ }^{1) 2)}$. 特に薄肉工作物の加工においては, チャック表面の平面度低下が工作物加工面に転写されるの で，加工精度を低下させる要因となる．また別のケースと して, 超精密正面切削を行う場合, 切削点が半径方向に移 動する際に，主軸回転による発熱にもとづき，主軸とこれ に固定した工作物が軸芯方向に熱変位し, 切り込み量が変 化することにより加工面の平面度が低下することが考えら れる，この場合，工作物外周のさらに外側において，露出 しているチャック面の変位を測定し，この情報にもとつい て切り込み量を制御寸るという加工精度向上対策が考えら れる，上記のいずれの場合にも，チャックの工作物吸着面 の平面度が良好に維持されることが必要である。

そこで, 変位はするとしても, 工作物吸着面の平面度変化

* 原稿受付 平成 13 年 6 月 19 日

** 正会員 新潟大学大学院自然科学研究科(新潟市五十嵐 2 の 町)
が極めて小さいチャックの構造設計を FEM 解析を援用して 実行することを目標とした. FEM 解析するには, アルミ合 金製チャック部品と鋼製主軸の間の相対変位を抑制する半 径方向の摩擦力, または両者の締結部における摩擦係数が 境界条件として必要である.ここでは, この摩擦力に相当 する接線外力を実験により求め, 接線外力とボルト締結時 のスラストとの比を締結部の等価摩擦係数として求めた.

これまでの報告では，鋼と電解仕上げしたアルミニウム間 の滑りにおける摩摖係数はほぼ $1.2^{3)}$ という例があるが， 荷重が 10mgf〜 10kgf とボルト締結時のスラストに比べ非常 に小さい，また，滑り速度によっても変化する可能性もあ $3^{4)}$ ので, チャック部品の熱変形による相対滑り速度のよ うに 5 10 $\mu \mathrm{m} / 10 \mathrm{~min}^{11}$ 程度の極めて遅い滑り速度におい ても適用できるかどうかは，明らかでない，そこで，実際 の熱膨張による相対滑り速度に近い条件下で等価摩擦係数 を求めるため，ピエゾ素子（PZT 素子）を用いて実験を行 った.

\section{2、実験装置と実験方法}

実験に用いた装置を図 1 に示寸。主軸と同一材料の S45C 鋼製主軸モデル(1)にアルミニウム合金製チャック部品(2)を ボルト(3)で締結している. ボルト(3)で加える主スラスト $N$ は，水晶圧電式の力変換器(4)をチャック部品(2)と厚めの座 金との間に設置して，測定している．Nは $2 \mathrm{kN}, 6 \mathrm{kN}, 10 \mathrm{kN}$ の 3 種類とした. PZT 素子(5)を伸長させることにより， グと力変換器(6)を介して, 主スラスト $N$ と垂直方向に，接 線外力 $F$ をチャック部品(2)に作用させた. PZT 素子の駆動 は，パソコン・12bit-D/A コンバータ・PZT 用電源を用いて 行った. 接線外力 $F$ をボルト(3)とチャック部品(2)の中心を 結ぶ線上に作用させるため, チャック部品の外周の一部を， 上記の作用線に垂直に加エしている.さらに，チャック部 


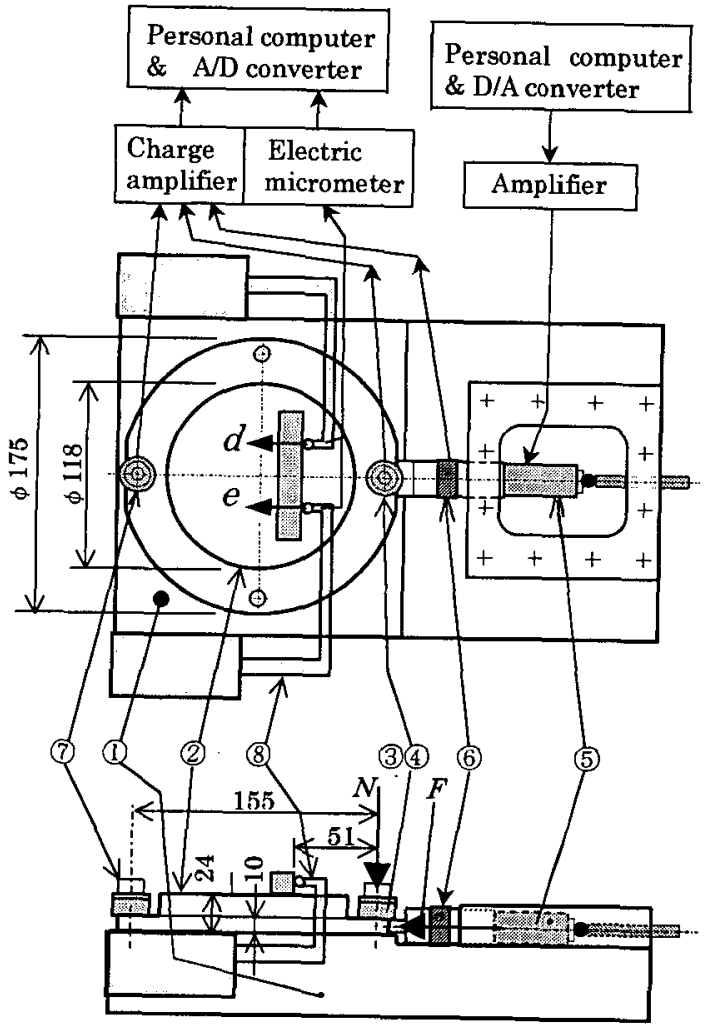

(a) General view of the setup

Fig.1 Experimental setup

(1):Steel model spindle , (2):Aluminum chuck-part, (3),(7):Bolt $N:$ Thrust force F:Tangential force correspondi

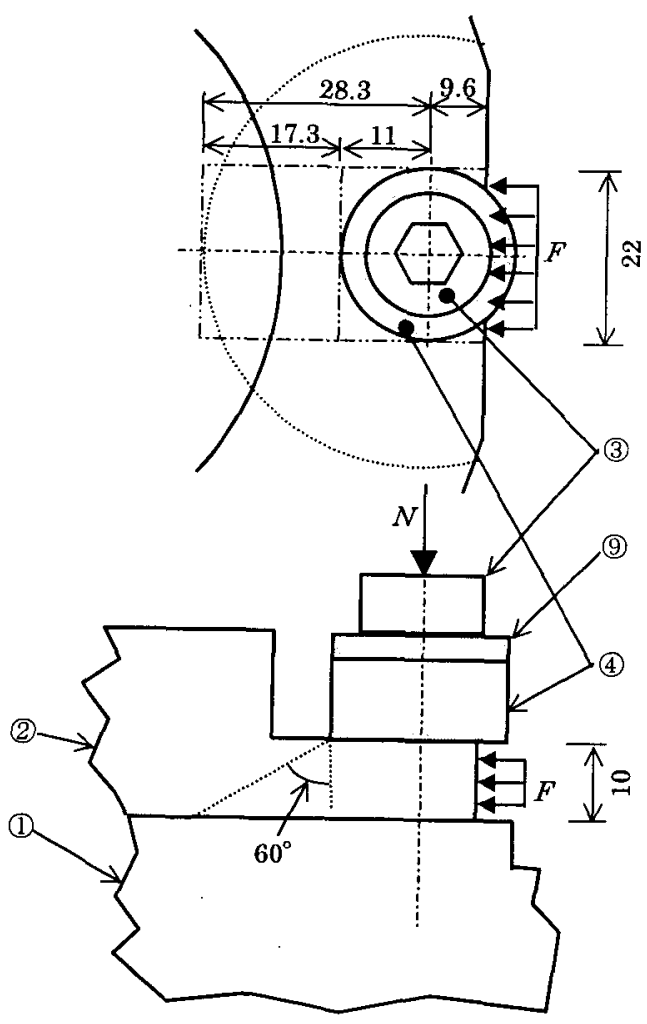

(b) Tangential force
(4),(6):Load sensor, ding to friction force

(8):Support for flectric micrometer
(5):PZT element

(9):Washer

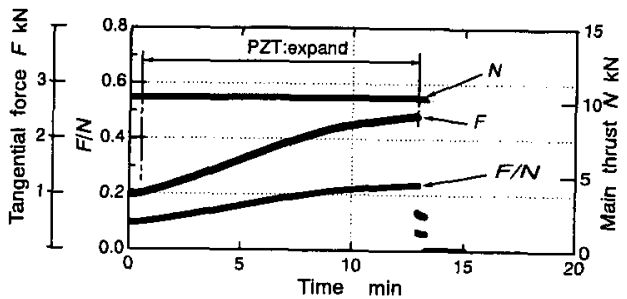

(a) Main thrust, tangential force and equivalent friction coefficient $F / N$

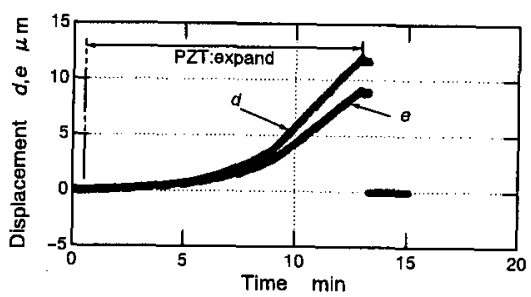

(b) Sliding displacement $d, e$

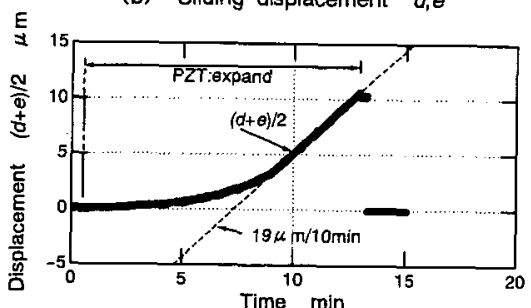

(c) Average sliding displacement $(d+e) / 2$

Fig.2 Example of experimental results

( $N=10 \mathrm{kN}$, increase speed of $P Z T$-input $=150 \mathrm{mV} / \mathrm{s}$, dry contact)
品と反対側において，PZT 素子を超硬チッブ, ベアリング ボールを介して，押しねじで支持している.

もう 1 つのボルト(7)には約 $200 \mathrm{~N}$ のスラストを作用させ

て，滑り変位中にチャック部品(2)の一部が主軸モデル(1)か ら浮き上がり，姿勢変化による接触領域の変化および電気 マイクロメータの測定変位への影響が生じないよう，注意 した，通常は 4 本のボルトでチャック部品を主軸に締結す るが, 本研究では(3)(7)の 2 本のボルトのみを用いた。

鋼製主軸モデルの接触面は平面研削し，表面粗さ $R_{\mathrm{a}}=$ $0.29 \sim 0.43 \mu \mathrm{m} の も の ， ア ル ミ$ 合金製チャック部品の接触 面は注意哚く旋削し， $R_{\mathrm{a}}=1.25 \sim 1.41 \mu \mathrm{m}$ のものを用いた。 アルミ合金製のチャック部品と鋼製主軸モデルとの間は, ウェスで拭いただけの乾式接触の場合およびスライド面用 の潤滑油をしみこませたウェスで拭いた湿式接触の場合に ついて実験を行った.

実験開始時の接線外力 $F$ は主スラスト $N$ の 5 10\%以下 とした. PZT 素子への印加電圧を $150,600,3000 \mathrm{mV} / \mathrm{s} の い$ ずれかの速度で増加させながら，このときの主スラスト $N$, 接線外力 $F$, チャックの変位, 押さえボルトのスラストを同 時サンプリング式の $12 \mathrm{bit}-\mathrm{A} / \mathrm{D}$ コンバータで計測した。 ヤックの変位は, 図1（a）に示すように，(1)に固定した 電気マイクロメータを用い接線外力 $F$ の作用線に関してほ ほ対称な 2 カ所において，チャック部品に固定したジグの 変位 $d$ と $e$ を測定し，その平均值とした．平均変位が 10〜 $15 \mu \mathrm{m}$ になるまで赛験を行った。チャック部品の回転変位 


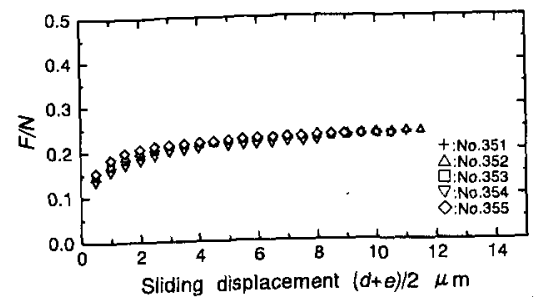

(a) Under increase speed of PZT-input=150mV/s

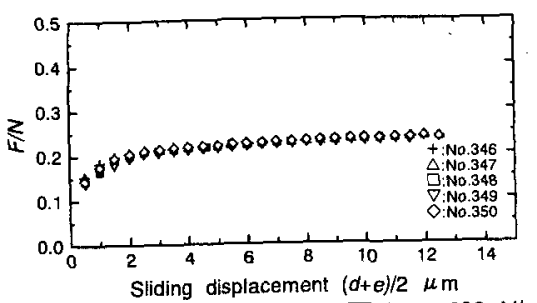

(b) Under increase speed of PZT-input $=600 \mathrm{mV} / \mathrm{s}$

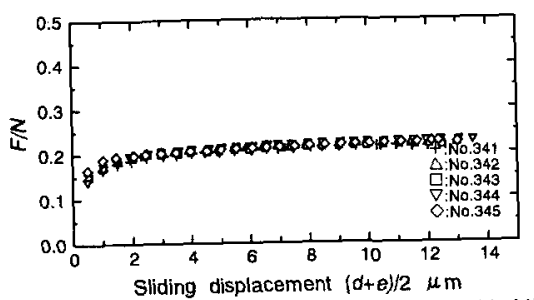

(c) Under increase speed of PZT-input $=3000 \mathrm{mV} / \mathrm{s}$

Fig.3 Equivalent friction coefficient and sliding displacement $(N=10 \mathrm{kN}$, dry contact)

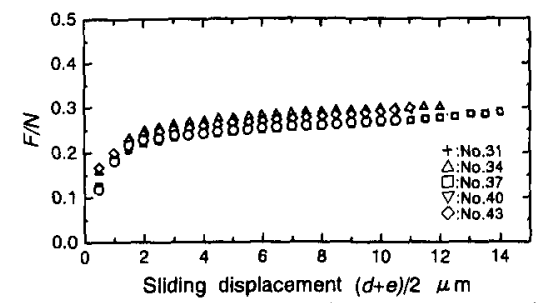

(a) Under increase speed of PZT-input $=150 \mathrm{mV} / \mathrm{s}$

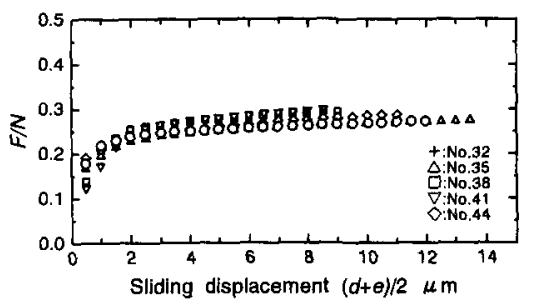

(b) Under increase speed of PZT-input $=600 \mathrm{mV} / \mathrm{s}$

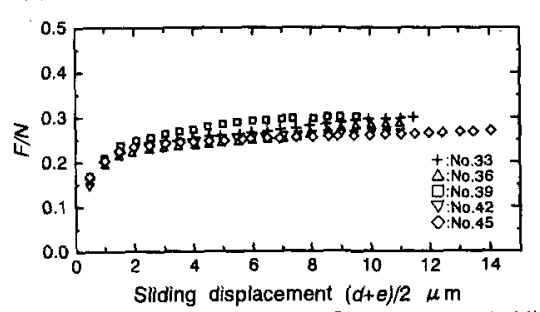

(c) Under increase speed of PZT-input $=3000 \mathrm{mV} / \mathrm{s}$

Fig.4 Equivalent friction coefficient and sliding displacement ( $N=6 \mathrm{kN}$, dry contact)

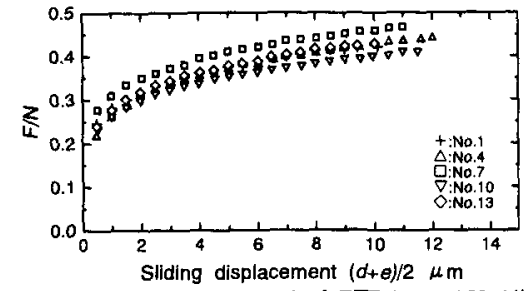

(a) Under increase speed of PZT-input $=150 \mathrm{mV} / \mathrm{s}$

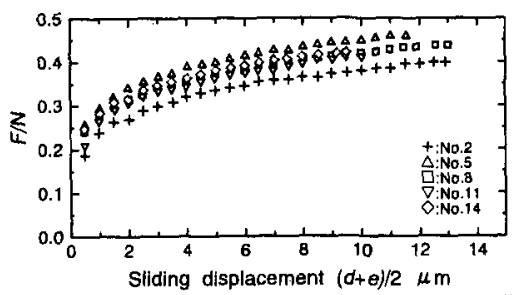

(b) Under increase speed of PZT-input $=600 \mathrm{mV} / \mathrm{s}$

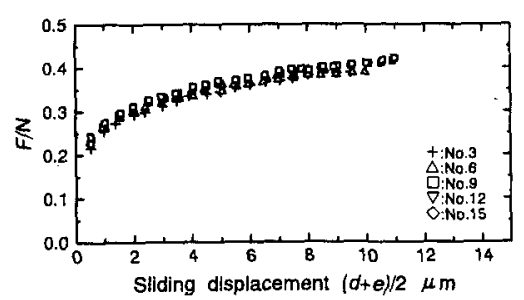

(c) Under increase speed of PZT-input $=3000 \mathrm{mV} / \mathrm{s}$

Fig.5 Equivalent friction coefficient and sliding displacement ( $N=2 \mathrm{kN}$, dry contact)

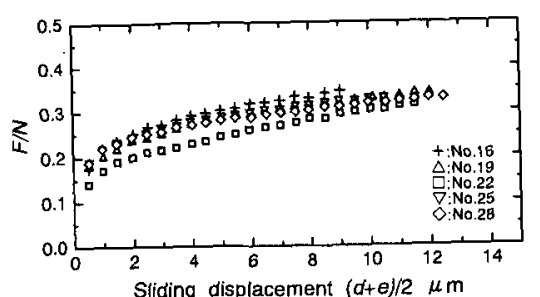

(a) Under increase speed of PZT-input=150 $\mathrm{mV} / \mathrm{s}$

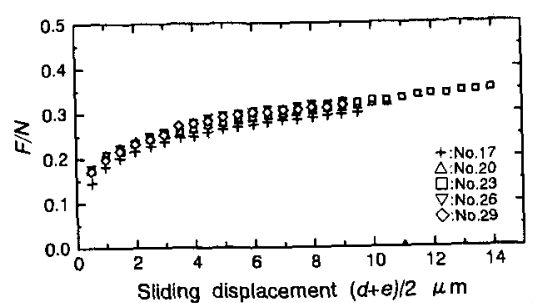

(b) 'Under increase speed of PZT-input $=600 \mathrm{mV} / \mathrm{s}$

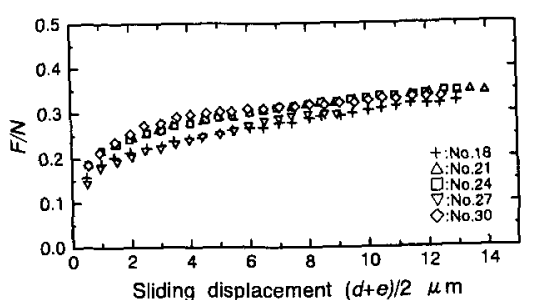

(c) Under increase speed of PZT-input $=3000 \mathrm{mV} / \mathrm{s}$

Fig.6 Equivalent friction coefficient and sliding

displacement ( $N=2 \mathrm{kN}$,wet contact)
が大きい場合のデータを除外するため，変位 $d$ と $e$ の差が 約 $20 \%$ 以内の場合を採用した。

\section{3. 実験の結果}

3.1 スラスト, 接線外力, 滑り変位の観察

アルミ合金製チャック部品(2)が鋼製主軸(1)に対し，相対 的に滑り始め, 平均滑り変位が約 $10 \mu \mathrm{m}$ に達するまでの害 験結果の1例を图 2 に示す。いずれの奏験においても，主 スラスト $N$ は実験中ほぼ一定値を示す，印可電圧が增加し，

PZT 素子が伸長するとともに，主スラスト $N$ に垂直に作用 する接線外力 $F$ が単調に増加している。このため, チャッ ク部品と主軸の締結部における等価摩擦係数 $F / N$ も単調に 増加することになる.PZT 素子が伸長を開始した直後にお いては，接線外力 $F$ の堌加にも関わらず，図 2（b）から 両者間の滑り変位はほとんど増加しないことがわかる。こ れは，接線外力の増加が主として PZT 素子前後の接触部の 弾性変形に消費されることによるものである．即ち，図 1 の押しねじと PZT 素子間には，接線外力 $F$ を垂直に作用さ せるための超硬チップとベアリングボールが存在し，これ らの接触部およびベアリングボールと押しねじの接触部の 弾性変形が生じることによるものと考えられる. 主として これらの弾性変形により，図2（b）において約 $2 \min$ まで の滑り変位 $(d+e) / 2$ は殆どぜロであり, その後, 滑り変位の 速度が上昇し，9〜13min における滑り変位の速度は約 19 $\mu \mathrm{m} / 10 \mathrm{~min}$ とほぼ一定值を示している，本研究においては， 滑り変位の値が小さいので, 変位速度の制御は行わず, PZT 素子への印加電圧の増加速度を一定とした．文献 1 ）図 4

(b) ( $\left.b^{\prime}\right)$ に見られるように, 熱変形による滑り開始 


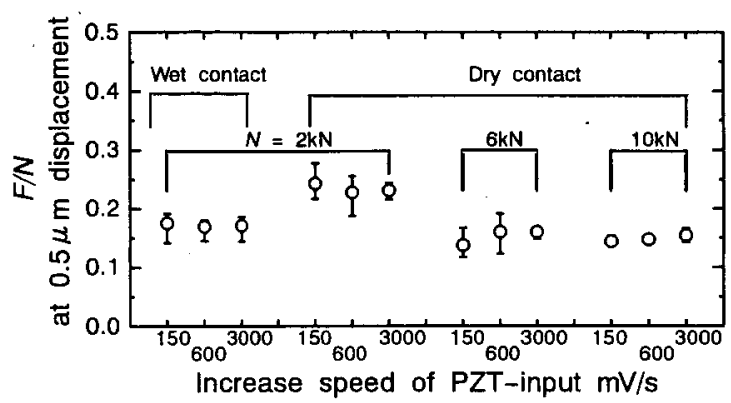

Fig.7 Equivalent friction coefficient at $0.5 \mu \mathrm{m}$ sliding displacement

Table 1 Shrinkage $d L_{(28.3)}$ of aluminum chuck-part over the portion of $28.3 \mathrm{~mm}$ in Fig.1(b)

\begin{tabular}{|r|l|l|l|}
\hline & $N=2 \mathrm{kN}$ & $6 \mathrm{kN}$ & $10 \mathrm{kN}$ \\
\hline$F=0.15 \times N$ & $0.14 \mu \mathrm{m}$ & 0.41 & 0.68 \\
$\sim 0.25 \times N$ & $\sim 0.23$ & $\sim 0.68$ & $\sim 1.13$ \\
\hline where; $d L_{(28.3)}=4.53 \times 10^{-4} \times F$ & $F$
\end{tabular}

付近の滑り変位の速度は 5〜10 $\mu \mathrm{m} / 10 \mathrm{~min}$ であった.これ に比べ上述の $19 \mu \mathrm{m} / 10 \mathrm{~min}$ は速いが, 図 2（c）のように 変位速度が連続的に増加しているので，滑りの初期には 5〜 $10 \mu \mathrm{m} / 10 \mathrm{~min}$ と同程度の速度を実現しているものと考えら れる.

\section{2 主スラスト，接触面一の油付着の影響}

図 2（c）において，滑り開始位置（: 滑り変位 $0 \mu \mathrm{m} の$ 位置) を特定することは事実上不可能である.そこで，同 一時刻における滑り変位 $(d+e) / 2$ と等価摩擦係数 $F / N$ の関係 を滑り変位 $0.5 \mu \mathrm{m}$ ごとにプロットして図 3 に示す. 等価摩 擦係数は連続的に比較的緩やかに変化しているので, 目的 とする FEM 解析の境界条件として用いるには，滑り変位 $0.5 \mu \mathrm{m}$ 以上に相当する等価摩擦係数を用いればよいものと 考えられる. 図 3 から, 主スラスト $10 \mathrm{kN}$ 乾式接触の場合 においては, 滑り変位が $2 \mu \mathrm{m}$ 以上で等価摩擦係数の増加割 合が小さいことが分かる。

図 4 は主スラスト $6 \mathrm{kN}$ ，乾式接触の場合の結果である. 図 3 に比心゙，等価摩擦係数がやや大きい，図 5 は主スラス 卜 $2 \mathrm{kN}$, 乾式接触の場合の結果である. 等価摩擦係数がさ らに大きくなり，図 3 の場合の約 2 倍であることがわかる.

つぎに，油が付着している湿式接触の場合における結果 を，図6に示す．図 5 乾式接触の場合に比べ，等価摩擦係 数が全体的に小さいのは接触面に塗布した潤滑油の効果と 考えられる. 滑り変位の増加とともに等価摩擦係数が増加 し，飽和していない傾向は，図 5 の場合と同様である.

3.3 滑り開始付近の等価摩擦係数

図 3 （a），(b)，（c）における PZT 素子への印加 電圧の増加速度は $150,600,3000 \mathrm{mV} / \mathrm{s}$ であり，その際の滑 り変位の最大速度はそれぞれ約 $20,80,400 \sim 500 \mu$ $\mathrm{m} / 10 \mathrm{~min}$ であった，滑り変位の最大速度は，図3〜図6の いずれにおいても，同程度であった。図2（c）に見られ るように，滑り速度は連続的に増加して，図 $3 \sim$ 図 6 の （a）では約 $20 \mu \mathrm{m} / 10 \mathrm{~min}$ の最大速度に到達した. 従って， 滑り開始付近では，熱変形による滑り変位速度 $5 \sim 10 \mu$ $\mathrm{m} / 10 \mathrm{~min}^{1)}$ を経過していることになる．また，本研究で得ら れた滑り速度の範囲では, 図 $3 \sim 6$ の場合に関して, 変位 速度が異なる（a）（b）（c）のいずれにおいても，等
価摩擦係数の大きさおよび等価摩擦係数の增加の傾向がほ とんど同一であることがわかる.

これまでの検討から，FEM 解析で用いる等価摩擦係数と して，滑り変位が $0.5 \mu \mathrm{m}$ における值を整理して图7に示す ボルトのスラストが大きいと等価摩擦係数はやや小さく， 接触面に油が存在すると等価摩擦係数が小さくなることが わかる，また，滑り速度が等価摩擦係数に及ぼす影響は，0 $\sim 500 \mu \mathrm{m} / 10 \mathrm{~min}$ 程度の速度範囲では，ほとんどないと言 える.

3.4 締結部の等価摩擦係数, チャック変位についての考察 本研究で定義した等価摩擦係数は，図 1 に示す接線外力 $F$ と(3)ボルトのスラスト $N$ の比である. 図 1 （b）に示す(3) ボルト付近の構造から，(1)(2)間の摩擦力と (4)(2)間の摩擦力 の合計が接線外力 $F$ に等しいと考えられる. 本研究ではこ れらの摩擦力を個々には特定していない。これらは FEM 解 析する際必要になるが，その作用範囲と作用力分布は設計 寸るチャック構造に依存して変化すると考えられる.ここ では，合計の接線外力 $F$ とスラスト $N$ の比として締結部の 等価摩擦係数を求めるに留め, FEM 解析を援用したチャッ ク設計において，これらの作用範囲と作用力分布を可能性 ある設計例について検討することにする。

接線外力を作用させ滑り変位を生じさせた際，チャック 部品(2)の一部が主軸モデル(1)から浮き上がることによる测 定変位への影響を抑制するため，(7)のボルトに約 $200 \mathrm{~N} の$ スラストを作用させている．200N のスラストは(3)のボルト スラスト $N$ の 10\%であるので, 実験で得られる接線外 カ $F$ は(3)ボルト.1本のスラスト $N$ による結果にほぼ一致す るものと考えられる.

つぎに，チャック部品(2)の変位 $d, e$ の測定位置は(3)ボ ルト中心と, 図 1 (a) に示すように, 約 $51 \mathrm{~mm}$ 離れてい るので, ボルト(3)の中心位置におけるチャック部品の滑り 変位と測定変位 $d, e$ とは同一でない可能性がある。そこ で両者の差について検討する, 両変位に差が生じる原因と しては，主軸モデル(1)からチャック部品(2)に作用する摩擦 力および力変換器(4)からチャック部品(2)に作用する摩擦力 と接線外力 $F$ によるアルミ合金製チャック部品(2)0)圧縮変 形が考えられる. (4)(2)間の接触力と(1)(2)間の接触力はいず 扎もスラスト $N$ に等しいので，两接触面間で作用する摩擦 力も同一であると仮定する．2つの接触面におけるこれら 摩擦力の合計が接線外力 $F$ に等しい。ここでは, (1)(2)間の 摩擦力の合計 $0.5 \times F$ による圧縮変形を, 以下のように実際 の值より大きめに計算したものを 2 倍して，全摩擦力 $F$ に よる検討中の圧縮変形を試算する.

ボルト(3)のスラスト $N$ による(1)(2)間の接触圧力分布は, 図 1 （b）に示寸力変換器(4)の投影面積内では一定で, そ の外側ではボルト中心から離れるとともに圧力円錐の半頂 角約 $60^{\circ}$ で減少するものと考えられる ${ }^{5)}$. 図 1 (b) にお いて, 半頂角 $60^{\circ}$ に対する区間の接触圧力分布が直線的に 変化し, 従ってこの区間の摩擦力が直線的に変化すると考 えられる.この範囲を半径 $28.3 \mathrm{~mm}$ の点線で示す：この範 囲の外側では，接触圧力は小さく，その結果作用寸る摩擦 力が小さいので, これによるチャック部品(2)の圧縮変形は 無視できるものと考えられる.ここで，半径 $28.3 \mathrm{~mm}$ の点 線で示す範囲の摩擦力によるチャック部品(2)の圧縮変形を 検討する：この範囲に作用する摩擦力の合計を，この範囲 


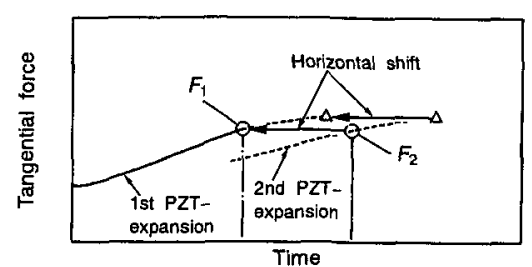

(a) Combining of tangential force

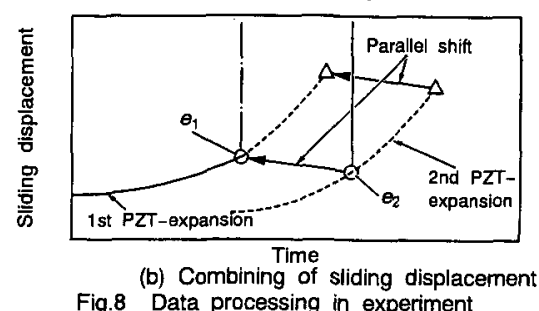

Fig.8 Data processing in experiment with multiple PZT-expansion

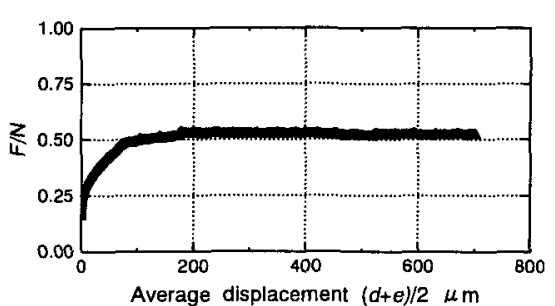

(a) $N=2 \mathrm{kN}$

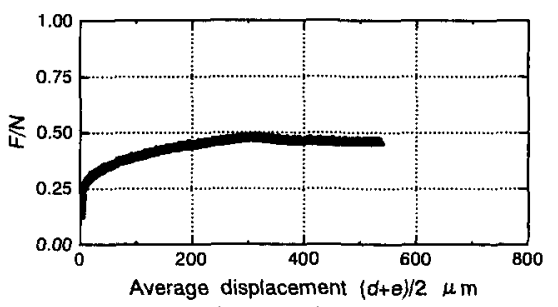

(b) $\mathrm{N}=6 \mathrm{kN}$

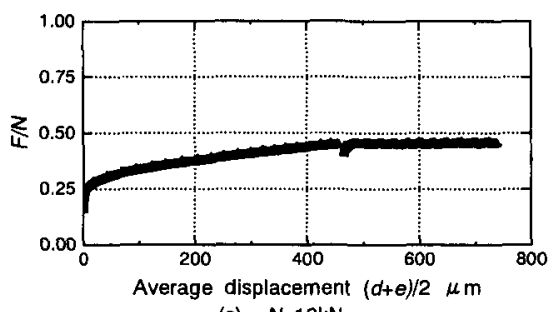

(c) $N=10 \mathrm{kN}$

Fig.9 Equivalent friction coefficient under longer displacement (dry contact, increase speed of $P Z T$-input= $600 \mathrm{mV} / \mathrm{s}$ )

に比べてかなり狭い $22 \mathrm{~mm} \times(9.6+28.3) \mathrm{mm}$ の範囲に分布 するものとする．即ち，実際に比べ，摩擦力が大きめの状 態で計算していると考えられる。この中 $22 \mathrm{~mm} \times(9.6+$ 11) $\mathrm{mm}$ の範囲には均一な摩擦力が分布し, これと同一の摩 擦力から直線的に減少しゼロになる摩擦力が $22 \mathrm{~mm} \times$ $17.3 \mathrm{~mm}$ の範囲に分布するものとする. (1)(2)間に作用するこ れら摩擦力の合計を $0.5 \times F$ とした．上記の摩擦力による $22 \mathrm{~mm} \times(9.6+28.3) \mathrm{mm} \times 10 \mathrm{~mm}$ の部材の圧縮変形のうち, $28.3 \mathrm{~mm}$ に対する変形が $d, e$ の測定位置から(3)ボルト中心 までの $51 \mathrm{~mm}$ 区間の圧縮変形であると考えられる．実際の チャック部品では幅 $22 \mathrm{~mm}$ に隣接する領域が存在するが, この部分による抑制効果を無視している点からも，実際に 比べ圧縮変形が大きめの状態で計算していることになる。 この変形は $0.5 \times F$ に対する変形であるので，これを 2 倍し
て, 全摩擦力 $F$ に対する圧縮変形を求めたものを表 1 に示 す。通常の $\phi 10 \mathrm{~mm}$ ボルトによるスラストは $6 \mathrm{kN} \sim 10 \mathrm{kN}$ の範囲にあるので, ボルト(3)の中心位置におけるチャック 部品の滑り変位と測定変位 $(d+e) / 2$ との差は $1 \mu \mathrm{m}$ 以下であ ると考えられる. 従って, 図 3〜図6のデータは水平方向 右側に $1 \mu \mathrm{m}$ 程度移動した位置にプロットすべきであること になる．しかし，等価摩擦係数 $F / N$ の滑り変位 $(d+e) / 2$ に対 寸る勾配はそ扎ほど大きくないので，滑り開始時の F/N は 図 7 の值を用いても差し支えないと考えられる.

3.5 長距離滑りにおける摩擦係数

図 3〜図 6 の結果は, 滑り変位の増加とともに等価摩擦 係数が增加することを示している.しかし，一般的に，滑 りが発生する前には摩擦力が増加し, 摩擦力が最大静止摩 擦力を越える状態で滑りが発生する，滑りが生じた後は滑 り変位が増加するのみで，摩擦力はほぼ一定の值を示す。 従って，摩擦係数は一定になると考えられる．この考え方 と図 3〜図 6 の結果が矛盾しないこと, 従って本研究で得 られた結果が妥当なものであることを明らかにするため，

これまでに比べて長距離の滑り変位に対する等価摩擦係数 を求める.

本研究で用いた PZT 素子は 1 回の伸長で最大約 $15 \mu \mathrm{m}$ 伸 びるだけである．長距離変位を生じさせるには複数回の PZT 素子の伸長を実行する必要がある，そこで，まず1回 目の PZT 伸長を行い，十分な滑り変位が得られない場合は， 一端 PZT 素子を収縮させた状態で, 直前の最大接線外力の およそ50\%の初期外力になるように押しねじを押し込んで, 再び PZT を伸長させるという操作を繰り返した。この際の 接線外力の測定值の結合および変位の測定值の結合を図 8 の要領で行った. 即ち, 第 1 回目の PZT 素子の伸長におけ る接線外力の最大值 $F_{1}$ に一致寸る 2 回目の接線外力 $F_{2}$ 以降 のデータを時間軸方向にのみシフトさせて，接線外力を結 合する. 上記の接線外力 $F_{2}$ と同一時刻の変位 $e_{2}$ は時間軸方 向に同一量シフトさせ，且つ第 1 回目の $F_{1}$ と同一時刻の変 位 $e_{1}$ と一致するよう上下方向にもシフトさせる.これは, 複数回の PZT 素子の伸長を実行するプロセスにおいても, ただ 1 回のみで十分な変位が得られる場合においても，同 一の接線外力が作用している状態では滑りの状況が同一で あると考えたからである，得られた実験データによれば， 第 1 回目の PZT 伸長による滑り変位は, 図 2 (c) に見ら れるように，緩やかに増加する助走区閒の後，ほぼ一定の 勾配で増加するが，第 2 回目以降の滑り変位は殆ど助走す ることなく急にほぼ一定の勾配で増加した。

以上の操作を行って得られた約 $700 \mu \mathrm{m}$ までの長距離滑 りにおける等価摩擦係数の変化を图 9 に示す. 主スラスト の大きさに関わらず，等価摩摖保数が約 0.5 に収束すること， 主スラストが小さい場合は, 図 5（b）のように滑りの開 始時から大きめの等価摩擦係数であるので, 図 9（a）の ように速やかに 0.5 に収束することがわかる. 以上の検討か ら，図 3〜図 6 の結果は力学の一般的な考え方に反するも のではなく，収束前の経過的な状況であることが分かる． 従って, 図 3〜図 7 の結果は妥当なものであると考えられ る。

即ち，乾燥摩擦に関する経験則であるクーロンの法則の 3 番目の項目（；静摩擦力は動摩擦力より大きい） ） 1 番目， 2 番目の項目と同様に，面圧や速度が極端に高い場 
合および低い場合を除いて近似的に成立することが多い ${ }^{4)}$ 言われている，本研究は滑り速度が極めて低い場合である ので，第 3 番目の項目が成立していないが，実験結果の妥 当性を否定するものではないと考えられる. また, 数 $\mu \mathrm{m}$ 程度の微小な滑り変位の場合にも，本研究の結果と同様に， 滑り変位の増加とともに接線力が増加することが報告され ておう ${ }^{6)}$ ，第 3 番目の項目が成立しない例である.

\section{4. 結論}

熱膨張係数が異なる部品を組み合わせた構造物について， 熱膨張の差にもとづく形状変化が極めて小さくなるように FEM 解析を援用して構造設計することを目的とし, 境界条 件に用いる等価摩擦係数を実験により求めた。ここで, 締 結部の等価摩擦係数とは（接線方向の作用外力/ボルトの スラスト)である。

(1) PZT 素子を用いて駆動することにより，アルミ合金 製チャック部品と銅製主軸との間に， $2 \mathrm{kN} \sim 10 \mathrm{kN}$ のボ ルトスラストが実際とほぼ同一の締結状態で作用して いる条件において，熱変形による実際の滑り速度に近 い 0 500 $\mu \mathrm{m} / 10 \mathrm{~min}$ 程度の極めて遅い速度で, 滑り変 位を生じさせることができた．また，この方法を用い て締結部の等価摩擦係数を求めた.

(2) FEM 解析で用いる締結部の等価摩擦係数は, 滑り開 始付近において約 $0.15 \sim 0.25$ ，滑りの距離が増加する とともに増加することが分かった．数百 $\mu \mathrm{m}$ の滑り距 離に执いては，等価摩擦係数は約 0.5 で飽和する。

本研究においては，チャック部品・主軸間の摩擦力 とそれ以外の部品間の摩擦力を分離していない．従っ
て，FEM 解析を用いて設計を行う場合，チャック部 品・主軸間のみが滑り変位する場合, チャック部品・ 主軸間だけでなく, 例えば, チャック部品・力変換器 間が滑り変位する場合あるいはチャック部品・ワッシ ヤ間が滑り変位する場合についても解析し検討する必 要があると考えられる.

\section{謝辞}

本研究について，4 年次学生として協力された丸山和志 君, 永井豊君に感謝します。

\section{参 考 文 献}

1)横山和宏, 山田和孝 : 超精密加工用真空チャックの熱変形 による平面度変化の解析（第 1 報 真空チャックの熱的 挙動) 精密工学会誌, 64 巻 8 号(1998)1201-1205 頁

2)横山和宏, 山田和孝 : 超精密加工用真空チャックの熱変形 による平面度変化の解析（第 2 報 平面度変化のメカ二 ズムの実験による解明) 精密工学会誌, 64 巻 10 号 (1998)1472--1476 頁.

3)バウデン・テイバー著, 曾田範宗訳 : 固体の摩擦と潤滑, P89, 丸善（株）。

4) 日本潤滑学会編：改訂潤滑ハンドブック, P28,P41, （株）盖賢堂.

5)伊東誼 : 工作機械のボルト結合部に関する最近の研究状況, 精密機械, 40 巻 6 号(1974)P480--488.

6)例えば，鏡重次郎，川口尊久，烟沢鉄三，藤本隆士，吉岡 直人 : セラミックス接触面の接線力による微小変位特性, トライボロジスト, 45 巻 8 号(2000)636--644 頁.
深緑の季節となりましたが，会員の皆様におかれましては元気 にお過ごしのことと存じます. 今月は，マイクロアクチュエータ の特集を企画いたしました. マイクロマシンを始めとした微小化 技術，微小加工技術等は，現在注目されている最先端技術であ り，半導体，医療等広い分野で応用が期待されています．基礎技 術や応用分野が広いこともあって，特集の“ネタ”としては非常 に豊富で, 当学会でも度々取り上げてまいりましたが, アクチュ エータに特化した企画は今回が初めてとなります.

機械を駆動する上で，アクチュエータはなくてはならない重要 な要素となっています，微小機構を動かすにあたっては，当然ア クチュエータも小型化する必要があります．使い勝手の良い従来 型モータの小型化技術は非常に重要となってきます。また，微小 化が進むと“慣性”よりも“粘性”が大きく影響してくることが 知られています.マイクロマシンの駆動源としては, 従来型とは
違った新しい発想のアクチュエータが適してくることも予想に難 くありません，そこで本号では, マイクロアクチェエータの将来 展望, 従来型モー夕の小型化技術, 新しい発想（技術）を用いた 小型駆動機構について, 専門家の皆様にわかりやすく解説してい ただきました。

冒頭でも述べましたが，マイクロマシンを始めとする機械の微 小化技術は非常に重要となってきました，空想とされていた“ミ クロ決死隊”も夢てはなくなってきたように思います。微小機械 に使用するアクチュエータに関しまして,ご参考となれば幸いで す.

最後になりましたが，ご多忙中にもかかわらず，本特集の解説 記事をご執筆いただきました著者の方々に厚く御礼申し上げま す.

（野口昭治） 